[12] Slyvka, N. B., Bilyk, O. Y., Mikhailytska, O. R., Nagovska, V. O. (2019). Improvement of technology of curd products with succade from pumpkin. Scientific Messenger of LNU of Veterinary Medicine and Biotechnologies, 21 (92), 47-52. doi: https:// doi.org/10.32718/nvlvet-f9209

[13] Zyablitseva, M. A., Dolmatova, I. A. (2013). Vliyanie ovoschnyh tsukatov na kachestvo i bezopasnost' yogurtov. Aktual'nye problemy sovremennoy nauki, tehniki i obrazovaniya: materialy 71-y mezhdunarodnoy nauchno-tehnicheskoy konferentsii, $1,255-258$.

[14] Josipović, R., Medverec Knežević, Z., Frece, J., Markov, K., Kazazić, S. (2015). Nutrition Quality and Microbiological Safety of Novel Cottage Cheese. Food Technology and Biotechnology, 53. doi: https://doi.org/10.17113/ftb.53.04.15.4029

[15] Golubkina, N. A., Fedorova, M. I., Stepanov, A. N., Nadezhkin, S. M. (2014). Content of micro- and macro-elements of parsnip (Pastinaka Sativa L.). Vegetable Crops of Russia, 3, 18-21. doi: https://doi.org/10.18619/2072-9146-2014-3-18-21

[16] DSTU 4503:2005. Izdeliya tvorozhnye. Obschie tehnicheskie usloviya (2006). DP «UkrNDNTS», 14.

[17] GOST 31680-2012. Massa tvorozhnaya «Osobaya». Tehnicheskie usloviya (2014). FGUP «Standartinform», 8.

[18] Golubkina, N. A., Fedorova, M. I., Stepanov, A. N., Nadezhkin, S. M. (2014). Content of micro- and macro-elements of parsnip (Pastinaka Sativa L.). Vegetable Crops of Russia, 3, 18-21. doi: https://doi.org/10.18619/2072-9146-2014-3-18-21

\title{
INVESTIGATION OF THE INTENSIVE TECHNOLOGY OF FOOD SPROUTS USING ORGANIC ACIDS
}

\author{
Olena Kovaliova ${ }^{1}$ \\ livre@i.ua \\ Yuriy Tchursinov ${ }^{1}$ \\ agro-1@mail.ru \\ Viktoriia Kalyna ${ }^{1}$ \\ viktoriya-kalina@ukr.net \\ Tatyana Khromenko \\ Internet Agency Msystem \\ 10 Mikhail Grushevsky str., Dnipro, Ukraine, 49000 \\ Tat5Ka2687@gmail.com

\section{Ekaterina Kunitsia} \\ Kharkov Trade and Economic Institute of Kiev National Tradeand Economic University \\ 8 O. Yaroshlane, Kharkiv, Ukraine, 61045 \\ ekaterina.kunitsia@gmail.com \\ ${ }^{1}$ Dnipro State Agrarian and Economic University \\ 25 Serhiia Efremova str., Dnipro, Ukraine, 49600
}

\footnotetext{
Abstract

The features of the intensive technology of getting food sprouts with organic acids as an intensifier of germination were studied. The aim was to establish the features of the intensive technology of producing sprouts of different crops with using organic acids at germination (butanedioic, 3-pyridine carbonic, pteroylglutamic). It is important to search new and safe germination stimulators of universal use. Such substances are just the studied organic acids, because positive changes of quality parameters of a ready product are traced at their use in the sprout technology. There was studied the sprout technologies that includes washing, disinfection, step-by-step air-water soaking of grains from different crops and their germination. As a disinfectant and growth stimulator at the stage of grain material soaking, there were used water solutions of the organic acids in the concentration diapason from 0.025 to $2.5 \mathrm{~g} / 1$. Due to their
} 
use, it became possible to get high-quality healthy food products, namely sprouts of different crops. Organic acid solutions stimulate the germination process and allow to get an essentially higher amount of high-quality sprouts in shorter terms without chemical toxic admixtures. The research results of the influence of the mentioned organic acids on germination indices of different grains materials are presented. Optimal values of concentrations of active substances in solutions have been established. Comparing with the classic technology of using these acids as a growth stimulator for sprouts allows to decrease the total duration of material germination in 1.5-2 times. Due to that it becomes possible to initiate the industrial production of sprouts. The experimental studies proved the effectiveness of using organic acids at getting living sprouts. It is demonstrated, that their use allows not only to intensify grains germination, but also favors more active formation of sprouts. The presented technology of producing sprouts of different crops is innovative. The obtained grain raw materials may be used independently or as an important component of new food products.

Keywords: food products, organic acids, butanedioic acid, 3-pyridine carbonic acid, pteroylglutamic acid.

DOI: $10.21303 / 2504-5695.2020 .001204$

\section{Introduction}

Sprouts of cereal crops gain wide popularity as a valuable component of the human food ration. Their value is conditioned by natural biological properties of the whole living organism that is a grain of crops.

A grain material in the rest condition contains substances, necessary for the growth and development of a future plant. But it must be noted, that grain lipids, proteins and carbohydrates have a complex structure, and enzymes of the human digestive system must split these complex substances of a grain in simpler at eating products of grains. The lack of enzymes in the human organism results in the low level of assimilation of extremely important food components, that is why it is advisable, that complex grain components are split by enzymes at germination. Grain germination is the process of its transformation from the rest condition to the sprout growth. At the fixed temperature and humidity a grain swells, begins to breathe intensively, absorbs necessary mineral substances and microelements from water, an amount of vitamins in the grain material increases. At germination hydrolytic enzymes of a grain split complex proteins, lipids and carbohydrates in simpler substances, necessary for the sprout formation. So, at eating grain sprouts, a human organism receives and assimilates substance, processed by enzymes. A germination grain has a great energetic potential, contains all vitally important components that must be easily assimilated by the human organism. Sprouts consumption compensate a vitamin and mineral deficit, stimulates metabolism, favors cleaning of the human organism from slag, favors digestion, improves immunity, brakes organism aging processes. At including sprouts into the ration, the acid-alkaline balance of the organism normalizes. Sprouts of each crop have a specific set of healthy substances, vitamins and microelements [1-3].

\section{Problem review}

Present promising directions of improving the traditional technology of getting a sprout material are directed at: creation of conditions, most favorable for germination; shortening of the production process of sprouts by optimizing soaking and germination parameters.

Different methods of activation of a grain material are used for this aim: physical (ultrasound waves, ionized radiation, electromagnetic fields, incoherent red light), chemical (diammonium phosphate, potassium bromide), physical-chemical (plasmochemical processing of water solutions) and microbiological (enzymatic preparations) [4-9].

Most popular are intensification methods, based on using special chemical substances biostimulators of grain germination. The most spread among them are: gibberellic, milk, ferulic, indolil acetic acids; coumarin [10,11]. At producing sprout grains, alkyl esters of arachidonic, eicosapentoenoic or jasmine acids with an antioxidant are used as growth stimulators [12]. The method of barley germination that provides adding biochemical processes of the complex of organic acids at the soaking stage as a stimulator is promising [13].

The following organic acids are used in technological processes of barley germination: fruit (apple, grape, lemon), amber, nicotine, folic and their complexes [14-16]. Unfortunately, their use in the process of getting food sprouts has not been studied. 
An important aspect of the study is a high quality of the obtained grain raw materials [17, 18]. The special attention must be also paid to the microbiological condition of sprouts, because it influences their quality and storage term $[19,20]$.

All this allows to talk about prospects of studies as to using organic acids, because they are able not only to intensify germination processes, but also partially disinfect grain raw materials.

The aim of the study is to establish a possibility of using water solutions of butanedioic, 3 -pyridine carbonic and pteroylglutamic acids in the process of getting food sprouts of cereal crops.

The task of the study is to select organic acids for their further use; to fix the influence of different concentrations of acids of energy and germination ability of different crop grains; to fix peculiarities of the technological process of germination at chosen germination intensifiers.

\section{Materials and methods}

Research materials: grains of different crops (wheat, spelt, barley, rye, oats, German wheat, sorgo, teff, corn, pea, bean, haricot bean, soya, adzuki, cowpea, guar, kayan, lobia, mush, nut, urad, lentil, peavine, wika, pigweed, buckwheat, dagussa, quinoa, mogar, millet, rice, Itallian millet, amaranth, sunflower, rape, flax, triticale); sprout grains of these crops at different research stages; water solutions of the organic acids, chosen as growth activators: 3-pyridine carbonic (nicotine) acid that is an acceptor and intermediate agent of water atoms at initial stages of oxidation of carbohydrates and fatty acids, has a weak anticoagulant effect and participates in the metabolic process of lipids, proteins, amino acids and so on; pteroylglutamic (folic) acid, because it is able to rehabilitate itself to the coenzyme, favoring the synthesis of nucleic acids; butanedioic (amber) acid, participating in processes of cellular breathing, oxidation of carbohydrates, lipids and able to stimulate the growth and to raise productivity of crops [14-16].

For estimating the initial quality of the grain raw materials, there were used standard methods, corresponding to the requirements of existent normative-technical documents: organoleptic parameters, full-scale mass, contamination with microorganisms vermins of bread reserves, content of admixture, humidity by SSU 4138-2002; the germination process was realized according to this standard.

The energy and ability to growth were determined by conventional methods (SS 10968-88). The sprout length was also fixed during the whole process for establishing the dynamics of sprouts formation under the effect of the chosen germination intensifier.

The change of the microbiological condition of the grain material was observed under the microscope MBS-10, and outwashes were inoculated on the nutrient medium with the further calculation of colonies of microorganisms.

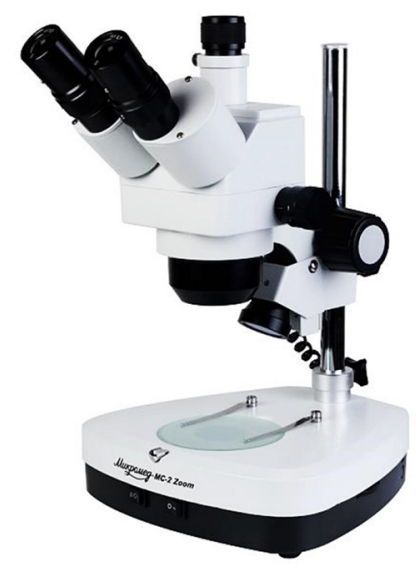

Fig. 1. Microscope MBS-10

\section{Experiments}

All types of grain material were preliminarily studied for their correspondence to the existent standards. Grains of the presented crops were sprouted in the laboratory malt-house that is a 
set of plastic volumes, covered by the layer of filtering paper and soaked in the organic acids of a correspondent concentration.

The grain material was processed by water solutions of the organic acids in the following way: the grain material, prepared for germination, was saturated by the acid solution of the given concentration in two stages. The previous soaking was realized during 4 hours at temperature $18-20{ }^{\circ} \mathrm{C}$. After finishing the term, the nutritive solution was poured away, and the grains were kept for 18 without a liquid. At the repeated soaking, there were used acid solutions of the analogous concentration. For preventing souring of the solutions, alkali solutions were added to the grains at the second stage of soaking. The air-water soaking was conducted during 26 hours up to ther complete saturation of grains by the preparation. Germination was conducted during 3-15 hours at temperature $17-21^{\circ} \mathrm{C}$, periodically moisturizing and moving the grain layer with the height no more $45-55 \mathrm{~mm}$ for evenly distributing the liquid and preventing mass compression. The final stage of the technological process was the further processing of sprouts: comminution, cooling or drying, depending on technological need.

The moisture of the grain material at soaking in the solutions of organic acids was determined during the first four hours.

Important parameters of sprouted grains and quality of food sprouts are energy and ability to cereal crops germination. Low-quality sprouts with a great number of not germinated grains are received from grains with low physiological parameters. That is why it is important to determine such parameters as energy and germination ability, and at using germination intensifiers, as in our case, their determination gains extreme importance, because they allow to estimate the effectiveness of using organic acids in the sprouts preparing technology. For determining the effectiveness of the influence of these growth intensifiers on energy and germination ability, batches of 500 grains were formed. Water solutions of butanedioic, 3-pyridine carbonic, pteroylglutamic acids in the concentration diapason from 0.025 to $2.5 \mathrm{~g} / 1$ were used for soaking. The germination energy was fixed in 72 hours after the beginning of soaking, the germination ability - after 120 hours. The indices were expressed in percents of sprouted grains to the total number of grains. The additional monitoring of the change of the sprout length was conducted during 15 days. At the same time there was determined the number of microorganisms on the sprout surface of all crops. The number of microorganisms was determined by calculating colonies, revealed on standard mediums. The iteration of all experiments was threefold. The results are presented as mean values.

\section{Results}

A grain is a capillary-porous colloid body with the cellular structure and many macro- and micropores, it has sorption properties, so is able to absorb water and its steam and desorption ones (moisture return), that is hygroscopic. It must be noted, that the faster a grain absorbs a necessary amount of water, the faster biological processes of germination and germination will be. So, just at the beginning of germination we can talk about the effective use of intensifiers, because the water-absorbing ability change in a grain demonstrates the effectiveness of the impact of the water solution of the organic acids on the research object (grain).

An important aspect of the germination technology is the grain material moisture, so the monitoring of its change was conducted. The mean results are given in Table 1.

Analyzing the results, presented in Table 1, we can made a conclusion that the use of water solutions of butanedioic, 3-pyridine carbonic, pteroylglutamic acids allows to reach the moisture level, necessary for enzymes activation that is $48-50 \%$, much faster than by the classic technology (using ordinary water). The increase adsorption ability of the grain material forms by supporting the constant acidity that, in its turn, favors the synthesis and accumulation of substances, accelerating the growth and development of a grain.

Concentrations of the organic acids in diapason $0.025-2.5 \mathrm{~g} / 1$, demonstrated the maximal increase of energy and germination ability were chosen by the way of preliminary analysis. The research results are presented in Table 2. 
Table 1

Monitoring of the water-absorbing ability change in different crops at contacting with the solutions of organic acids

\begin{tabular}{ccccc}
\hline & \multicolumn{3}{c}{ Grain material moisture, \% } \\
\cline { 2 - 5 } Soaking duration, min & control (water) & \multicolumn{3}{c}{ Water solutions of organic acids } \\
\cline { 3 - 5 } & 14 & butanedioic & 3-pyridine carbonic & pteroylglutamic \\
\hline 30 & 20 & 21 & 28 & 36 \\
50 & 29 & 25 & 26 & 37 \\
60 & 34 & 36 & 36 & 39 \\
90 & 39 & 38 & $\mathbf{4 3}$ & 40 \\
120 & 40 & 39 & $\mathbf{4 4}$ & 41 \\
130 & 41 & 41 & $\mathbf{4 5}$ & $\mathbf{4 2}$ \\
150 & $\mathbf{4 6}$ & $\mathbf{5 2}$ & $\mathbf{4 3}$ \\
180 & $\mathbf{4 2}$ & $\mathbf{4 2}$ & $\mathbf{5 5}$ & $\mathbf{4 4}$ \\
210 & $\mathbf{4 4}$ & $\mathbf{4 7}$ & $\mathbf{5 7}$ & $\mathbf{4 6}$
\end{tabular}

Analyzing the results, presented in Table 1, we can made a conclusion that the use of water solutions of butanedioic, 3-pyridine carbonic, pteroylglutamic acids allows to reach the moisture level, necessary for enzymes activation that is $48-50 \%$, much faster than by the classic technology (using ordinary water). The increase adsorption ability of the grain material forms by supporting the constant acidity that, in its turn, favors the synthesis and accumulation of substances, accelerating the growth and development of a grain.

Concentrations of the organic acids in diapason $0.025-2.5 \mathrm{~g} / \mathrm{l}$, demonstrated the maximal increase of energy and germination ability were chosen by the way of preliminary analysis. The research results are presented in Table 2.

Table 2

Energy and germination ability of cereal crops at using the optimal concentrations of the organic acids

\begin{tabular}{|c|c|c|c|c|c|c|c|c|}
\hline \multirow{3}{*}{ Crop } & \multicolumn{4}{|c|}{ Germination energy, \% } & \multicolumn{4}{|c|}{ Germination ability, \% } \\
\hline & \multirow{2}{*}{$\begin{array}{l}\text { Control } \\
\text { (water) }\end{array}$} & \multicolumn{3}{|c|}{ Water solutions of organic acids } & \multirow{2}{*}{$\begin{array}{l}\text { control } \\
\text { (water) }\end{array}$} & \multicolumn{3}{|c|}{ Water solutions of organic acids } \\
\hline & & $\begin{array}{l}\text { butane- } \\
\text { dioic }\end{array}$ & $\begin{array}{l}\text { 3-pyridine } \\
\text { carbonic }\end{array}$ & $\begin{array}{l}\text { pteroylglu- } \\
\text { tamic }\end{array}$ & & $\begin{array}{l}\text { butanedi- } \\
\text { oic }\end{array}$ & $\begin{array}{l}\text { 3-pyridine } \\
\text { carbonic }\end{array}$ & $\begin{array}{l}\text { pteroylglu- } \\
\text { tamic }\end{array}$ \\
\hline 1 & 2 & 3 & 4 & 5 & 6 & 7 & 8 & 9 \\
\hline Wheat & 85 & 88 & 87 & 89 & 90 & 92 & 93 & 94 \\
\hline Spelt & 84 & 87 & 88 & 88 & 92 & 94 & 95 & 95 \\
\hline Barley & 87 & 90 & 91 & 90 & 95 & 97 & 97 & 98 \\
\hline Rye & 88 & 91 & 91 & 92 & 93 & 95 & 95 & 96 \\
\hline Oats & 86 & 90 & 90 & 89 & 92 & 94 & 95 & 94 \\
\hline German wheat & 84 & 88 & 89 & 88 & 90 & 92 & 93 & 93 \\
\hline Sorgo & 85 & 89 & 88 & 87 & 91 & 93 & 94 & 94 \\
\hline Teff & 88 & 91 & 91 & 92 & 91 & 93 & 94 & 93 \\
\hline Triticale & 87 & 90 & 91 & 90 & 91 & 94 & 94 & 93 \\
\hline Corn & 85 & 88 & 88 & 89 & 90 & 92 & 92 & 93 \\
\hline Pea & 84 & 87 & 88 & 87 & 90 & 92 & 92 & 93 \\
\hline Haricot bean & 82 & 86 & 86 & 85 & 88 & 91 & 90 & 91 \\
\hline Bean & 81 & 85 & 86 & 86 & 89 & 91 & 92 & 92 \\
\hline
\end{tabular}


Continuation of Table 2

\begin{tabular}{|c|c|c|c|c|c|c|c|c|}
\hline 1 & 2 & 3 & 4 & 5 & 6 & 7 & 8 & 9 \\
\hline Soya & 85 & 88 & 89 & 89 & 90 & 92 & 93 & 92 \\
\hline Adzuki & 82 & 86 & 86 & 85 & 88 & 91 & 92 & 92 \\
\hline Cowpea & 85 & 89 & 88 & 88 & 90 & 94 & 94 & 93 \\
\hline Guar & 84 & 88 & 88 & 87 & 90 & 93 & 93 & 92 \\
\hline Kayan & 83 & 86 & 87 & 87 & 89 & 92 & 92 & 93 \\
\hline Lobia & 85 & 88 & 89 & 89 & 90 & 94 & 93 & 94 \\
\hline Mush & 82 & 86 & 85 & 86 & 88 & 91 & 91 & 92 \\
\hline Nut & 85 & 88 & 89 & 88 & 90 & 93 & 93 & 94 \\
\hline Urad & 82 & 86 & 86 & 85 & 88 & 90 & 91 & 91 \\
\hline Lentil & 84 & 88 & 87 & 87 & 90 & 92 & 93 & 93 \\
\hline Peavine & 86 & 89 & 90 & 90 & 92 & 94 & 96 & 95 \\
\hline Wika & 85 & 88 & 89 & 88 & 91 & 94 & 94 & 93 \\
\hline Buckwheat & 86 & 90 & 89 & 89 & 92 & 94 & 95 & 95 \\
\hline Dagussa & 81 & 84 & 85 & 85 & 88 & 90 & 91 & 91 \\
\hline Quinoa & 82 & 86 & 85 & 85 & 88 & 90 & 90 & 91 \\
\hline Mogar & 85 & 88 & 89 & 89 & 90 & 92 & 93 & 93 \\
\hline Millet & 83 & 87 & 86 & 86 & 88 & 90 & 92 & 92 \\
\hline Rice & 80 & 84 & 83 & 84 & 88 & 90 & 90 & 91 \\
\hline Italian millet & 83 & 87 & 86 & 86 & 88 & 90 & 91 & 91 \\
\hline Pigweed & 85 & 88 & 89 & 89 & 93 & 97 & 96 & 96 \\
\hline Millet groats & 86 & 90 & 90 & 89 & 93 & 95 & 95 & 96 \\
\hline Amaranth & 83 & 87 & 85 & 86 & 90 & 92 & 92 & 93 \\
\hline Sunflower & 82 & 86 & 85 & 86 & 90 & 93 & 94 & 94 \\
\hline Rape & 81 & 85 & 84 & 84 & 87 & 91 & 90 & 91 \\
\hline Flax & 82 & 86 & 85 & 85 & 89 & 92 & 91 & 92 \\
\hline
\end{tabular}

At that the mentioned concentrations of the organic acids in water solutions didn't impair grains at the experiments and didn't cause changes of organoleptic properties of the ready product. For impartiality of the analysis, there were determined the above calculated indices in different cereal crops for fixing the distinct and comparative image of the course of biological processes in the grain material.

The results, presented in Table 2, testify that intensification of the germination process is stable for all cereal crops. Thus, energy and germination ability in all crops steadily increased by $2-4 \%$ at using the offered organic acids, and that is an important parameter for industrial production of sprouts.

The change of the sprout length was fixed. The obtained results are presented in Fig. 2, 3.

Analyzing the obtained results, we can make a conclusion about more intensive development of sprout, fixed at using the organic acid solutions at soaking. It must be also noted, that the evenness of the intensive growth of sprouts is observed in the ridge that testifies to the evenness of the germination process in all grains and to shortening terms of getting food sprouts. in Table 3.

The influence of the organic acids on the microbiological condition of sprouts is presented

Local disinfecting properties of organic acids were studied. Table 3 presents the data of microbiological contamination at using the studied organic acids on different types of grain raw materials. The disinfecting ability is more expressed in samples with a higher concentration of the organic acids. It is explained by the fact that an acid medium negatively influences pathogenic microorganisms on the crop grain surface and their sprouts. 


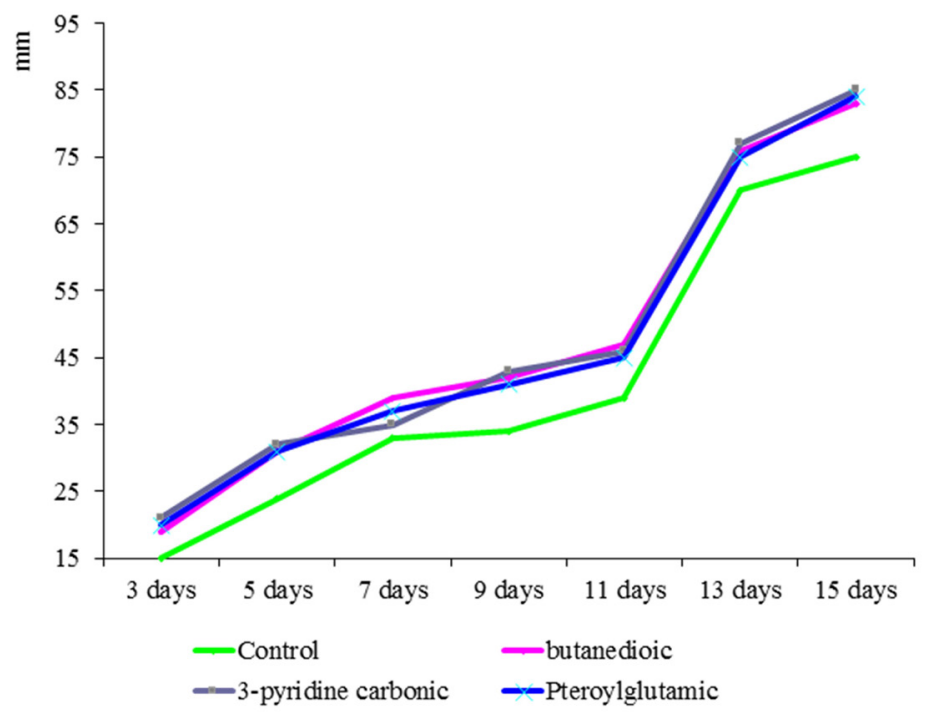

Fig. 2. Dynamics of crop sprout length change at using the organic acids
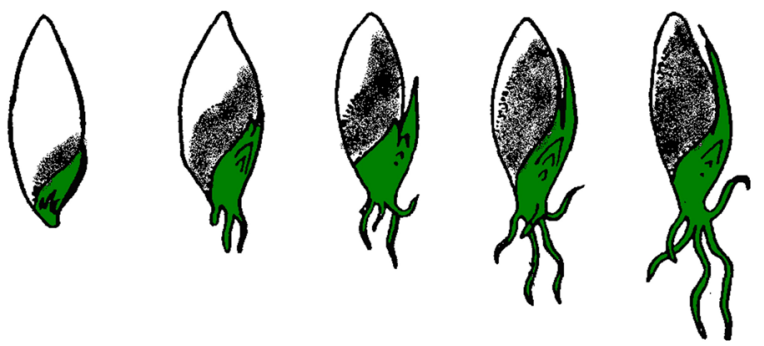

$a$
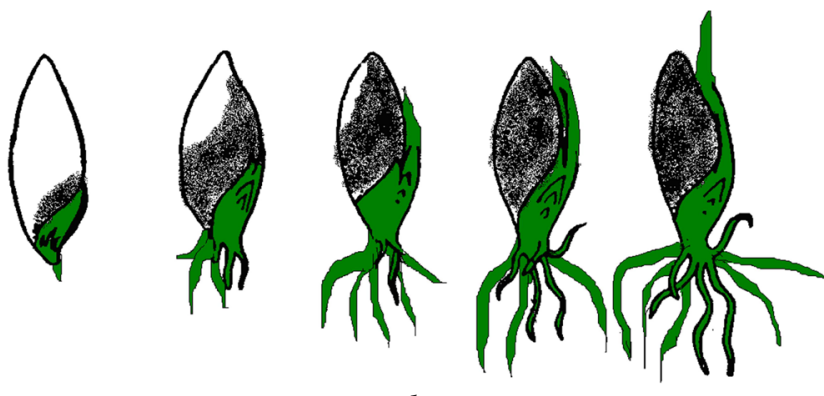

$b$

Fig. 3. Monitoring of the sprout length change:

$a$ - control (using ordinary water); $b$ - experiment (using the organic acid solutions)

Table 3

The study of the microbiological condition of sprouts at using the organic acids

\begin{tabular}{ccccc}
\hline \multirow{2}{*}{$\begin{array}{c}\text { Concentration of } \\
\text { organic acids, mg/l }\end{array}$} & control & butanedioic & 3-pyridine carbonic & pteroylglutamic \\
\cline { 2 - 5 } & $7.4 \cdot 10^{6}$ & $<10$ & $<10$ & $<10$ \\
2.5 & $7.4 \cdot 10^{6}$ & $<10$ & $<10$ & $<10$ \\
1.5 & $7.4 \cdot 10^{6}$ & $1.2 \cdot 10^{2}$ & $1.0 \cdot 10^{2}$ & $1.1 \cdot 10^{2}$ \\
1.0 & $7.4 \cdot 10^{6}$ & $1.8 \cdot 10^{3}$ & $2.0 \cdot 10^{3}$ & $1.9 \cdot 10^{3}$ \\
0.5 & $7.4 \cdot 10^{6}$ & $4.0 \cdot 10^{4}$ & $4.2 \cdot 10^{4}$ & $4.1 \cdot 10^{4}$ \\
0.025 & $7.4 \cdot 10^{6}$ & $4.5 \cdot 10^{5}$ & $4.4 \cdot 10^{5}$ & $4.6 \cdot 10^{5}$
\end{tabular}




\section{Discussion}

The obtained results testify that the chosen organic acids can intensify the process of getting food sprouts. It has been established, that the use of solutions of butanedioic, 3-pyridine carbonic, pteroylglutamic acids in the concentration diapason from 0.025 to $25 \mathrm{~g} / 1$ at germination of a grain allows to get the high-quality grain product in shorter terms that is testified by the increase of energy and germination ability indices. The most positive technological results were obtained at the following concentrations of the organic acids: butanedioic - 0,752,25 g/1, 3-pyridine carbonic - 0.250-0.500 g/l, pteroylglutamic $-0.025-0.250 \mathrm{~g} / 1$ depending on cereal crop. Sprouts form faster in all studied crops, and it gives a possibility to get more high-quality grain material. At using the organic acids, the microbiological contamination of sprouts decreases, because the pathogenic microflora is partially inhibited, increased the food quality of the ready product.

At selecting optimal concentration parameters of the organic acids in water solutions, the germination effectiveness increases and gives a possibility to talk about absolute prospects of the offered germination technology of cereal crops for food aims.

\section{Conclusions}

The production technology of food sprouts using the organic acids allows to get the high-quality product, enriched with organic acids, necessary for the human organism in safe amounts, in shorter terms (2-5 days, depending on cereal crop). It has been proved, that water solutions of butanedioic, 3-pyridine carbonic, pteroylglutamicacids have properties, allowing to accelerate moisture adsorption by grains and as a result to shorten the process of getting sprouts in $1.5-2$ times. The energy and germination ability in cereal crops increases mainly by $2-4 \%$ at using solutions of the studied growth intensifiers. At that the organic acids can manifest disinfecting properties.

So, the technology of getting food sprouts of cereal raw materials of different crops using water solutions of butanedioic, 3-pyridine carbonic, pteroylglutamic acids is ecologically safe and effective, so may be introduced in production at any enterprise, specialized in sprouts.

\section{Acknowledgments}

All studies were conducted on the base of the Scientific-production laboratory of quality determination of grain and grain products of Dnipro state agrarian-economic university (Ukraine).

\section{References}

[1] Hübner, F., Arendt, E. K. (2013). Germination of Cereal Grains as a Way to Improve the Nutritional Value: A Review. Critical Reviews in Food Science and Nutrition, 53 (8), 853-861. doi: http://oi.org/10.1080/10408398.2011.562060

[2] Butenko, L. I., Legai, L. V. (2013). Researches of the chemical composition of germinated seeds of the buckwheat, oats, barley and wheat. Fundamental research, 4 (5), 1128-1133.

[3] Miachikova, N. I., Binkovskaia, O. V., Chizhova, S. V., Rudycheva, E. V. (2012). Ispolzovanie proroschennykh semian v sostave produktov pitaniia. Izvestiia VUZOV. Prikladnaia khimiia i biotekhnologiia, 2 (3), 149-152.

[4] Agu, R. C., Devenny, D. L., Tillett, I. J. L., Palmer, G. H. (2002). Malting Performance of Normal Huskless and Acid-Dehusked Barley Samples. Journal of the Institute of Brewing, 108 (2), 215-220. doi: http://doi.org/10.1002/j.2050-0416.2002. tb00543.x

[5] Lewis, M. J., Young, T. W. (2001). Malting technology: malt, specialized malts and non-malt adjuncts. Boston: Aspen Publishers Inc, 48-70. doi: http://doi.org/10.1007/978-1-4615-1801-3_4

[6] Pivovarov, O. A., Tyshchenko, H. P., Ponomarenko, Yu. V., Kovalova, O. S. (2013). Vplyv plazmokhimichno obroblenoi vody na protses roshchennia zhytnoho solodu i yoho yakisni pokaznyky. Kharchova nauka i tekhnolohiia, 3 (24), 82-86.

[7] Pivovarov, O. A., Kovalova, O. S., Chursinov, Yu. O. (2009). Vyrobnytstvo solodu z vykorystanniam aktyvovanykh pid diieiu nerivnovazhnoi plazmy vodnykh rozchyniv. Visnyk Dnipropetrovskoho derzhavnoho ahrarnoho universytetu, 2, 194-197.

[8] Meledyna, T. V., Prokhorchyk, Y. P., Kuznetsova, L. Y. (2013). Byokhymycheskye protsessi pry proyzvodstve soloda. Saint Petersburg: NYU YTMO; YKhyBT, 89. 
[9] Kovaliova, O., Perkova, A., Savitchenko, K. (2018). Ozonation features of technological solutions in the malt production. Bulletin of the National Technical University «KhPI» Series: New Solutions in Modern Technologies, 45 (1321), 166-172. doi: http://doi.org/10.20998/2413-4295.2018.45.23

[10] Khosni, R. K. (2006). Nauchnye osnovy i tekhnologii pererabotki zerna. Saint Petersburg: Professiia, 336.

[11] Szwajgier, D., Pielecki, J., Targonski, Z. (2005). Changes of free ferulic and coumaric acid contents during malting of barley grain. Polish Journal of Food and Nutrition Sciences, 14 (4), 423-429.

[12] Kvasenkov, O. I., Lomachinskii, V. A., Gorenkov, E. S. (1999). Pat. 2148627 RU. Sposob proizvodstva soloda. MPK 51 S 12 S 1/047. No. 99100140/13; declareted: 05.01.1999; published: 10.05.2000, Bul. No. 13.

[13] Kiseleva, T. F., Miller, Iu. Iu., Grebennikova, Iu. V., Stabrovskaia, E. I. (2016). Vozmozhnost intensifikatsii solodorascheniia posredstvom ispolzovaniia kompleksa organicheskikh kislot. Tekhnika i tekhnologiia pischevykh proizvodstv, 40 (1), $11-17$.

[14] Pivovarov, O., Kovaliova, O., Khromenko, T., Shuliakevych, Z. (2017). Features of obtaining malt with use of aqueous solutions of organic acids. Food Science and Technology, 11 (4), 29-35. doi: http://doi.org/10.15673/fst.v11i4.728

[15] Pivovarov, O., Kovaliova, O. (2019). Features of grain germination with the use of aqueous solutions of fruit acids. Food Science and Technology, 13 (1), 83-89. doi: http://doi.org/10.15673/fst.v13i1.1334

[16] Chursinov, Y. A., Kovaleva, E. S. (1970). Application of organic acids and its mixtures as a stimulator of seed germination. Vestnik of the Russian Agricultural Science, 6, 31-34. doi: http://doi.org/10.30850/vrsn/2019/6/31-34

[17] Guoping, Z., Chengdao, L. (2010). Genetics and Improvement of Barley Malt Quality. New York, 296.

[18] Narzib, L., Back, W., Gastl, M., Zarnkow, M. (2017). Abriss der Bierbrauerei. Wiley-VCH. doi: http://doi.org/10.1002/ 9783527812820

[19] Shishkova, Yu. S., Simonyan, E. V., Abramovskikh, O. S. et. al. (2014). The study of antimicrobial activity of some dibasic carboxylic acids in combination with propolis. Medical Almanac, 1 (31), 99-101.

[20] Khodunova, O. S., Silant'eva, L. A. (2017). Provision of microbiological safety of oat seed germination. Foods and Raw Materials, 5 (2), 145-150. doi: http://doi.org/10.21603/2308-4057-2017-2-145-150 